\title{
They earn and send; we spend: Consumption patterns of Pakistani migrant households
}

\author{
Junaid Ahmed \\ Faculty of Economics, Georg-August-Universitat Gottingen, \\ Gottingen, Germany and \\ Capital University of Science and Technology, Islamabad, Pakistan \\ Mazhar Mughal \\ Pau Business School, Pau, France, and \\ Inmaculada Martinez-Zarzoso \\ Georg August University, Goettingen, Germany and \\ University Jaume I, Castelló de la Plana, Spain
}

\begin{abstract}
This study analyzes differential consumption patterns of Pakistani migrant households resulting from foreign and domestic remittances. Using the Working-Leser model and a number of matching techniques, we analyze a large representative household survey carried out in 20102011 to compare various expenditure categories of recipient and non-recipient households across different income brackets. Findings show that foreign remittances lead to significant consumption changes. Contrary to the widely-held view, remittances do not raise the budget share on consumer goods and recreation, while the allocation on education increases substantially. Households receiving domestic remittances also show a strong focus on human capital with significantly higher shares of health and education. Recipients of international transfers living below one dollar a day spend proportionally more on food compared with their non-recipient counterparts, whereas their education and health budget shares are not dissimilar. We find that migrant households perceive remittances as a mainly transient source of income.
\end{abstract}

Key Words: Expenditure; Consumption patterns; International remittances; Domestic remittances; Pakistan.

JEL Codes: O12, O15 


\section{Introduction}

Migration, whether from villages to cities or from one country to another, can involve a change in consumption patterns of the migrants' households back home. This can take place in several ways. First, the money migrants remit leads to higher household income which can be

differentially consumed, saved or invested. Secondly, these monetary remittances help diversify the migrant household's sources of income depending on the extent the household and migrant incomes are correlated. Thirdly, migration exposes the households to new lifestyles and consumption behaviours. These social transfers generate different patterns of food, health, education, living and recreation expenditures. These marginal consumption patterns of remittances shape the growth and developmental effects of remittances on the migrants' home economy.

If the remittances lead to higher marginal shares of food, consumer goods and other non investment expenditures, they are thought to have minimal impact on the economic development of the community. Studies such as Chami et al. (2003) and Clément (2011) support this pessimistic view of remittances. On the other hand, Acosta et al. (2007), Adams (1998), Adams and Cuecuecha (2010a), Adams and Cuecuecha (2010b), Alderman (1996), Amuedo-Dorantes and Pozo (2011), Kifle (2007) and Taylor and Mora (2006) among others suggest beneficial effects of migrant remittances through improvements in the households' healthcare, educational attainment and higher investment in productive ventures.

According to Massey et al. (1987) and Russell et al. (1990), these beneficial investments occur once the migrant household's subsistence needs are satisfied. 
The impact of remittances on the households' expenditure behaviour crucially depends on how remittances are perceived by the recipient households. If given the nature of migration and the migrant's economic status, remittances are considered part of the household's permanent income; they will be treated just as other fungible sources of income and will therefore be consumed in similar fashion (Athukorala, 1990; Cardona Sosa and Medina, 2006). However, if remittances are perceived as a temporary income arrangement, they are more likely to be saved or invested than consumed (Adams, 1998). In this study, we argue that these two hypotheses need not be mutually exclusive, and may co-exist depending on the nature of remittances and household characteristics. We test this proposition by using a large representative household survey dataset carried out in Pakistan in 2010-2011 to examine the impact of foreign and domestic remittances on various expenditure categories of the migrant households' annual budgets as well as their respective shares in the household budget. We find that migrant households treat remittances as a temporary source of income and invest them to increase their human capital stock. However, this behavior is altered by the households' resource availability, as poor remittance recipients prefer spending a bigger share of their budget on food rather than education or health.

\section{Literature Overview}

Remittances are often found to be spent on consumption goods rather than saved or invested (Chami, Fullenkamp and Jahjah, 2003; Clément, 2011; Durand and Massey, 1992). Studies such as Chandavarkar (1980:39) and Tabuga (2007) assert that remittances are frittered away on consumer items symbolizing social status and ceremonies at the cost of more productive expenditures. Findings from other studies challenge this pessimistic view. Even though the

migrant household may increase its consumption spending as a result of receiving money from the migrant member of the household, the additional funds may improve the household's living 
conditions. Expenditure on more and better quality food leads to better nutrition and food security (Durand et al., 1996; Jimenez, 2009).

Moreover, part of the additional income is spent on goods such as education and health. Adams and Cuecuecha (2010b) in the case of Guatemala, Cardona Sosa and Medina (2006) in the case of Columbia and Kifle (2007) in the case of Eritrea find evidence of an increased share of education spending in the household budget resulting from migrant remittances. Similarly, studies such as Amuedo-Dorantes and Pozo (2011), Cardona Sosa and Medina (2006) and Yang (2005) report proportionally higher marginal health spending by migrant households. Acosta et al. (2007) examine the household consumption patterns of seven Latin-American countries and find a general decrease in the share of food and other consumption spending and a significant increase in the share of health spending among migrant households.

Some studies indicate that remittances lead to higher budget allocations on construction and repair of houses (Adams, 1991; Arif, 2009; Osili, 2004).

In certain economies, a greater proportion of remittances are invested to expand small scale businesses, purchase of necessary capital goods and machinery and finance new ventures (Taylor and Mora, 2006).

Some studies compare the consumption patterns of international and domestic remittances. The two kinds of remittances widely differ in their usage subject to the economic and demographic profiles of the migrants and migrant households. Clément (2011) for instance finds that recipients of international remittances in Tajikistan have a higher propensity to consume than to invest, while the consumption patterns of domestic Tajik remittance recipients do not differ significantly from the non-recipient households. His findings indicate that a higher proportion of 
household expenditure is devoted to healthcare among domestic migrant households, whereas no increase in budgetary allocation for health, education or other productive expenditures can be traced among the recipients of foreign transfers. In contrast, Castaldo and Reilly (2007) conclude that the consumption pattern for Albanian households receiving internal remittances is not statistically different from those that do not receive such transfers, whereas households who receive remittances from abroad spend, on average, a lower share of expenditure on food and a higher share on consumer durables compared to households who do not receive any type of migrant remittances.

The differential use of remittances discussed so far depends not only on the migrant's income and the consequent choice of the amount and frequency of remittance back home, but also on the socioeconomic profile of the migrant household. Remittances can add to the savings or invested gainfully once the household's basic consumption needs have been fulfilled (Russell et al., 1990). Remittances therefore represent a short-term coping strategy that allows the dependent households to achieve a basic level of consumption. A migrant household's consumption behaviour is also driven by its perception of remittances as transitory or permanent income. In the former case, remittances are more likely to be spent on physical or human capital investments than consumed (Adams, 1998). If remittances are treated as any other source of income (permanent income hypothesis), they would be considered fungible and thus spent just like other source of household income. Migrant households' propensity to consume may then not differ in any substantial manner from the non-migrant households (Athukorala, 1990; Cardona Sosa and Medina, 2006).

A few studies have examined the observed uses of Pakistani households receiving foreign remittances. Ahmed et al. (2010), for instance, find that foreign remittance recipients have higher 
budget shares devoted to food, consumer items and education. Arif (2005) analyzes the 20002001 Pakistan Socioeconomic Survey (PSES) and concludes that total per capita monthly expenditures of migrant households are at least $50 \%$ higher than the expenditures of their nonmigrant counterparts. Migrant households, on average, spend 38\% of the total expenditure on food while non migrant households spend an average of $46 \%$ on food items.

\section{Data description}

This study is based on the 2010-2011 round of Pakistan Social and Living-Standards Measurement Survey (PSLM) carried out on 16,341 households. The PSLM is a representative country-wide survey that collects data on household income, consumption, wealth, savings, work, social and demographic features. A two-step random stratified sampling scheme is adopted for the purpose with the sample stratified on a province and rural/urban basis. The survey dataset contains data on various sources of household income. A sizeable proportion of households (5.4\%) receive foreign remittances. The corresponding share for domestic remittances is even higher at (10.7\%). Table 1 presents demographic, consumption, economic and locational features of foreign and domestic remittance receiving households. Households receiving international remittances appear to be significantly different from those who do not receive remittances. Recipient households are substantially larger than non-recipient households. Similarly, recipients are at an average more educated and more often located in rural areas as compare to nonrecipient households. Heads of foreign remittance receiving households are older and somewhat less educated. $43 \%$ of the heads of recipient households are women as compared to $7 \%$ of the non-recipients, suggesting that many of the foreign migrants are male household heads in whose absence, women take up more household responsibilities. International migration from Pakistan is overwhelmingly male with few women going abroad for employment. Moreover, a smaller 
proportion of adults from recipient households works (43\%) as compared to non-recipient ones $(83 \%)$.

Table 1. Household Profile by Access to Remittances

\begin{tabular}{|c|c|c|c|c|c|c|}
\hline Variable & $\begin{array}{l}\text { HH with no } \\
\text { Foreign } \\
\text { Remittances } \\
\end{array}$ & $\begin{array}{l}\text { HH with } \\
\text { Foreign } \\
\text { Remittances } \\
\end{array}$ & $\begin{array}{l}\text { Two } \\
\text { sample T- } \\
\text { test } \\
\end{array}$ & $\begin{array}{l}\text { HH with no } \\
\text { Domestic } \\
\text { Remittances } \\
\end{array}$ & $\begin{array}{l}\text { HH with } \\
\text { Domestic } \\
\text { Remittances } \\
\end{array}$ & $\begin{array}{l}\text { Two } \\
\text { sample T- } \\
\text { test } \\
\end{array}$ \\
\hline \multicolumn{7}{|l|}{$\begin{array}{l}\text { Demographic } \\
\text { indicators }\end{array}$} \\
\hline Age of head & 46.26 & 48.82 & 4.01 & 46.03 & 49.46 & 6.85 \\
\hline Household size & 6.36 & 6.82 & 2.82 & 6.45 & 5.80 & -6.03 \\
\hline Dependency ratio & 0.49 & 0.54 & 4.53 & 0.49 & 0.54 & 6.32 \\
\hline $\begin{array}{l}\text { Number of adults } \\
\text { with schooling }\end{array}$ & 1.84 & 2.25 & 5.10 & 1.89 & 1.62 & -4.86 \\
\hline Sex of head & 0.07 & 0.43 & 16.11 & 0.06 & 0.40 & 20.27 \\
\hline Education of head & 2.31 & 2.15 & -2.04 & 2.33 & 1.99 & -5.99 \\
\hline $\begin{array}{l}\text { Marital Status of } \\
\text { head }\end{array}$ & 0.90 & 0.89 & -0.50 & 0.91 & 0.81 & -7.92 \\
\hline Workstatus of head & 0.83 & 0.43 & -17.21 & 0.85 & 0.48 & -19.86 \\
\hline \multicolumn{7}{|l|}{$\begin{array}{l}\text { Household } \\
\text { consumption } \\
\text { indicators }\end{array}$} \\
\hline Total expenditure & 197898.10 & 296255.80 & 6.95 & 205423.20 & 185418.00 & -2.00 \\
\hline Food & 75227.02 & 103198.20 & 9.05 & 77558.46 & 70096.30 & -3.76 \\
\hline Education & 7253.35 & 15604.62 & 6.23 & 7673.72 & 8006.37 & 0.40 \\
\hline Healthcare & 6272.66 & 8656.58 & 4.50 & 6212.24 & 7985.15 & 2.84 \\
\hline $\begin{array}{l}\text { Housing and } \\
\text { Utilities }\end{array}$ & 53664.00 & 72332.95 & 5.07 & 55597.31 & 47094.50 & -4.33 \\
\hline $\begin{array}{l}\text { Consumer non- } \\
\text { durables }\end{array}$ & 20231.83 & 29039.46 & 6.70 & 1025.68 & 546.65 & -5.34 \\
\hline Recreation & 966.85 & 1102.11 & 0.76 & 20885.22 & 19288.10 & -2.26 \\
\hline Others & 29364.22 & 51038.04 & 4.36 & 31082.34 & 26116.30 & -3.51 \\
\hline Durables & 4918.16 & 15283.87 & 2.17 & 5388.17 & 6283.89 & 0.65 \\
\hline \multicolumn{7}{|l|}{$\begin{array}{l}\text { Economic } \\
\text { Indicators }\end{array}$} \\
\hline $\begin{array}{l}\text { Local economic } \\
\text { conditions }\end{array}$ & -0.34 & 0.07 & 10.63 & -0.31 & -0.36 & -1.97 \\
\hline $\begin{array}{l}\text { Household } \\
\text { economic condition }\end{array}$ & -0.22 & -0.05 & 5.90 & -0.21 & -0.22 & -0.47 \\
\hline Asset index & 5.53 & 7.37 & 15.89 & 5.64 & 5.50 & -1.63 \\
\hline $\begin{array}{l}\text { Locational } \\
\text { Indicators } \\
\text { Region (rural/urban) }\end{array}$ & 0.35 & 0.25 & -3.86 & 0.36 & 0.19 & -10.80 \\
\hline $\begin{array}{l}\text { Province of } \\
\text { residence } \\
\text { (Punjab/others) }\end{array}$ & 0.41 & 0.37 & -1.47 & 0.43 & 0.25 & -8.66 \\
\hline
\end{tabular}

Source: Authors' calculations using PSLM (HIES) 2010-11. Note: Asset index based on Principal Component Analysis of 29 household assets. Local and household economic conditions take the values from -1 to 1 and indicate change in conditions relative to the preceding year. 
Houses of international remittance receiving households are better located, with shorter distances to public services and necessities such as drinking water, public transport, groceries and primary, middle and high schools. This suggests their relatively better economic status.

Households receiving domestic transfers likewise show some important differences with nonrecipient households (Table 1 Panel 2).

Like foreign remittance receiving households, recipients of internal remittances are predominantly based in villages and have older and less educated heads. However, unlike foreign remittance receiving households, domestic remittance receiving households are smaller and have fewer children and working age adults than the non receiving ones.

Socioeconomic and geographical characteristics of internal remittance receiving and nonreceiving households often show no statistically significant difference. Household expenditure for foreign remittance receiving households is substantially higher than that of non receiving households (Rs. 296,255 vs. Rs.197,898). Spending on all budget categories is higher among foreign remittance receivers. For instance, expenditure on food is about 50\% higher while expenditure on education and purchase of durable items is approximately $100 \%$ and $300 \%$ higher.

Table 2 show the budget shares of various expenditure categories for households receiving foreign and domestic remittances respectively. The budget share of education and durables is substantially higher among foreign remittance receivers; while that of food is significantly lower (39\% as compared to $41 \%$ ).

In contrast, total annual expenditure of internal remittance receiving households is slightly lower than that of non-recipient households (Table 1), showing that domestic remittances are usually 
received by households belonging to lower income groups. This is also apparent in lower food, housing and recreation expenditures and higher health spending among receivers of domestic remittances.

Table 2. Household Budget Shares by Access to Remittances

\begin{tabular}{lllllll}
\hline \hline $\begin{array}{l}\text { Consumption } \\
\text { indicators }\end{array}$ & $\begin{array}{l}\text { HH with no } \\
\text { Foreign } \\
\text { Remittances }\end{array}$ & $\begin{array}{l}\text { HH with } \\
\text { Foreign } \\
\text { Remittances }\end{array}$ & $\begin{array}{l}\text { Two } \\
\text { sample T- } \\
\text { test }\end{array}$ & $\begin{array}{l}\text { HH with no } \\
\text { Domestic } \\
\text { Remittances }\end{array}$ & $\begin{array}{l}\text { HH with } \\
\text { Domestic } \\
\text { Remittances }\end{array}$ & $\begin{array}{l}\text { Two } \\
\text { sample T- } \\
\text { test }\end{array}$ \\
\hline \hline Food & 41.02 & 39.04 & -3.24 & 40.99 & 40.29 & -1.29 \\
Education & 2.58 & 4.47 & 7.32 & 2.61 & 3.30 & 3.93 \\
$\begin{array}{l}\text { Health } \\
\text { Housing and }\end{array}$ & 3.39 & 3.39 & 0.00 & 3.26 & 4.47 & 6.21 \\
$\begin{array}{l}\text { Utilities } \\
\text { Recreation }\end{array}$ & 26.37 & 24.78 & -2.96 & 26.31 & 26.09 & -0.54 \\
$\begin{array}{l}\text { Consumer non- } \\
\text { durables }\end{array}$ & 0.42 & 0.32 & -3.63 & 0.43 & 0.22 & -9.78 \\
$\begin{array}{l}\text { Miscellaneous } \\
\text { Durables }\end{array}$ & 10.96 & 10.78 & -0.96 & 10.93 & 11.15 & 1.50 \\
\hline \hline
\end{tabular}

Source: Authors' calculations using PSLM (HIES) 2010-11

Compared to households receiving transfers from abroad, domestic remittance receivers allocate a higher share of the household budget to food, health and housing and a lower share to education expenditures (Table 2 Panel 2).

From the bivariate statistics shown above, an initial comparison between the households receiving the two types of transfers can be made: households receiving foreign transfers are larger and relatively more prosperous than either non foreign remittance receiving or domestic remittance receiving households They spend more on education, health and housing and have a lower budget share allocated to food despite spending more than other households. These descriptive statistics need to be interpreted with caution as they need to be controlled for various socioeconomic and demographic factors that distinguish the two types of households'. 


\section{Empirical methodology}

Model estimation proceeds in two steps. First, least squares are fitted to estimate the impact of remittances on household budget shares by employing the Working Leser specification. In the second step, a set of propensity score matching (PSM) techniques is used to control for potential selection bias present in the model by matching various observable characteristics of the recipient and non-recipient households. Probit model is used to calculate propensity scores. Common support is defined and average treatment effects on the treated (ATT) are consequently obtained using Nearest Neighbour (NN), Radius matching and Kernel matching methods.

\subsection{Model Specification}

Extant empirical literature has commonly employed the Engel curve framework to study the consumer behaviour. The approach has been applied to analyze the role of remittances in shaping household consumption patterns (see for instance Adams and Cuecuecha 2010b; Castaldo and Reilly, 2007; Taylor and Mora, 2006). In this framework, the quantity of a good or service consumed is taken as a function of the consumer's total expenditure and other control variables (Deaton \& Muellbauer 1999, p. 19). The estimation of this framework therefore requires a functional form such as the Working-Leser specification (Working, 1943; Leser, 1963). The Working- Leser model relates budget share linearly to the logarithm of total expenditure (Deaton $\&$ Muellbauer 1999, p. 19). A change in the share of a consumption category in response to a factor such as receipt of remittances can therefore reveal the relative importance of that item in the consumption basket.

The functional form of the specification employed in this study includes various economic, socio demographic and geographical variables in addition to the household's total expenditure, and can be given as: 
$\omega_{i j}=\beta_{i}+\gamma_{i}\left(\log E_{j}\right)+\delta_{i} R_{j}+\sum_{j} \mu_{i j} Z_{j}+\varepsilon_{i j}$

Where $\omega_{i j}$ represents expenditure share $i$ for household $j, E$ is the logged value of total expenditure of the household $j, R_{j}$ indicates whether or not the household receives international or domestic remittances, $Z_{j}$ represents the set of household characteristics that can affect expenditure behaviour and $\varepsilon_{i j}$ is the error term.

Table 3 gives the definition and means of the variables included in the equation.

Table 3. Variable description

\begin{tabular}{|c|c|c|}
\hline Variable & Description & Mean \\
\hline Foreign Remittances & $\begin{array}{l}\text { Dummy variable, takes the value of } 1 \text { if any member of the } \\
\text { household received remittances from abroad during last } 1 \\
\text { year, } 0 \text { otherwise }\end{array}$ & .054 \\
\hline Domestic Remittances & $\begin{array}{l}\text { Dummy variable, takes the value of } 1 \text { if any member of the } \\
\text { household received remittances inside Pakistan during last } 1 \\
\text { year, } 0 \text { otherwise }\end{array}$ & .107 \\
\hline Asset index & Index composed of various households assets & 5.63 \\
\hline Household size & Total number of family members in the household & 6.38 \\
\hline Dependency Ratio & $\begin{array}{l}\text { Share of members ages under } 18 \text { and above } 65 \text { in the } \\
\text { household }\end{array}$ & 0.50 \\
\hline Number of schooling18 & Number of adult members ever gone to school & 1.86 \\
\hline Age ofhead & Age of the households head in completed years & 46.3 \\
\hline Sex ofhead & $\begin{array}{l}\text { Dummy variable, takes the value of } 1 \text { if the household head } \\
\text { is a female, } 0 \text { otherwise }\end{array}$ & 0.09 \\
\hline Marital status of head & $\begin{array}{l}\text { Dummy variable, takes the value of } 1 \text { if the household head is } \\
\text { married, } 0 \text { otherwise }\end{array}$ & 0.92 \\
\hline Work statusofhead & $\begin{array}{l}\text { Dummy variable, takes the value of } 1 \text { if the household head is } \\
\text { employed, } 0 \text { otherwise }\end{array}$ & 0.81 \\
\hline Education ofhead & Number of years of schooling received by the household head & 2.30 \\
\hline $\begin{array}{l}\text { Household economic } \\
\text { condition }\end{array}$ & Current situation of household as compare to previous year & -0.21 \\
\hline $\begin{array}{l}\text { Local economic } \\
\text { condition }\end{array}$ & Current condition of the area as compare to previous year & -0.32 \\
\hline Region, & $\begin{array}{l}\text { Dummy variable, takes the value of } 1 \text { if the household } \\
\text { resides in rural area, } 0 \text { otherwise }\end{array}$ & 0.34 \\
\hline Province & $\begin{array}{l}\text { Takes the value of } 1 \text { if remittance recipient household lives in } \\
\text { Sindh, KPK, Baluchistan otherwise } 0\end{array}$ & 0.41 \\
\hline
\end{tabular}

Source: PSLM (HIES) 2010-11 


\subsection{Variable description}

\subsubsection{Consumption variables}

Annual expenditure of the sampled households is grouped into eight consumption categories namely food, education, health, housing, recreation, consumer items, durables and miscellaneous expenditures (Table 4). These categories are used to calculate shares in annual budget for each household. Household consumption includes the value of goods and services received in kind or own produced and consumed. Consumer items include goods for personal consumption which have a life expectancy of less than a year, such as clothing, footwear, medicine etc. Durable items are consumption goods with a life expectancy of one year or more, such as furniture, fixtures, television, radio, clocks, kitchen utensils etc. The miscellaneous category contains goods and services not included in any of the other expenditure shares.

Table 4. Description of expenditure categories

\begin{tabular}{ll}
\hline Expenditure category & Description \\
\hline Food & Milk and Milk Product, Meat Poultry and Fish, Fresh Fruits, Dry \\
& Fruits and Nuts, Vegetables, Condiments and Spices, Sugar and \\
& Honey, Non-Alcoholic Beverages, Ready-made Food, Drinks etc. \\
& Cereals, Pulses, Edible oil and Fats, Tea and Coffee, Miscellaneous \\
& Food items. \\
\hline Health & Medical care \\
\hline Housing and Utilities & Housing rent and Housing expenses, Chinaware, Earth ware, Plastic \\
& ware, and other households effects. Fuel and Lighting , \\
\hline Education & Communication (Telephone, telegraph, internet etc ) \\
\hline Recreation & Educational and Professional stationary Supplies Expenditure. \\
\hline Consumer Non-durables & Recreationand Reading \\
\hline Personal Care Services, Personal Care Articles, Household Laundry \\
cleaning and paper article, Clothing, Clothing material land services, \\
Footwear and repair charges, Personal effects and Services and repair \\
charges. \\
\hline Transport expenditure, Taxes and fine and all other miscellaneous \\
expenditure, Tobacco and Chewing product, \\
\hline Households textile and Personal effects, Kitchen appliances, \\
Furniture, Fixture and Furnishing, Other Households effects, TV, \\
VCP/VCR, Radio, Cassette player, Computer, Miscellaneous \\
\hline
\end{tabular}

Source: Authors' calculations using PSLM (HIES) 2010-11 
Different expenditure outlays have different periodicities (weekly, monthly, and yearly). These outlays are annualized to create comparable consumption categories.

\subsubsection{Economic indicators}

Economic indicators considered include foreign and domestic remittances, household wealth, the number of adult household members at work and the employment status of household head ${ }^{1}$.

Following Adams and Cuecuecha (2010b) and Castaldo and Reilly (2007), we take binary measures of remittances as our primary remittance indicators. Household wealth status is proxied by an asset index that consists of 29 indicators of property ownership, quality of housing and access to amenities. Principal Component Analysis (PCA) is used to obtain the first component of the assets holding index in order to explain the largest amount of information common to the constituent variables. The list of variables that constitute the asset index along with their respective scores are given in the appendix.

The poverty indicator takes households living below the US $\$ 1.25$ purchasing power parity poverty line as poor, and is calculated by using annualized per capita adult equivalent household income. A modified OECD equivalence scale is employed assigning weights of $1,0.5$ and 0.3 to the household head, other adults and minors at home respectively. Household incomes in Rupees are converted into US Dollars by using an average exchange rate of Rs. 85.19 per US Dollar for the year 2010-2011. The corresponding household income thus calculated for the $\$ 1$ poverty line is Rupee 38869.68. Using these figures, the country's $\$ 1$ poverty rate is estimated to be $24.3 \%$ in 2010-2011.

Along with household income, two subjective measures of household and local economic conditions are included. The measures take the values of $-1,0$ or 1 depending on whether the 
household or the area underwent a deterioration, no change, or an improvement in economic conditions compared with the situation prevailing in the preceding year.

\subsubsection{Socio-Demographic indicators}

The level of household consumption depends on the household's demographic composition (Ando and Modigliani, 1963). Household size, number of children, adults and the elderly determine the specific needs and drives household spending in different expenditure categories. Dependency ratio is defined as the share of children (less than 18 years old) and the elderly (60 years or above) in the household.

Head's age, sex, marital and employment status and level of education are included to gauge the head's role in defining a household's consumption behavior.

\subsubsection{Locational variables}

The two geographical indicators included account for rural/urban and province of residence. The categorical variable for provincial residence takes Punjab as the baseline. Punjab is the most populous province of Pakistan, accounting for 56\% of the country's population. The other three provinces are Sindh, Khyber Pakhtunkhwa (KP) and Baluchistan.

\subsection{Least Squares and Tobit models}

The modified Working Leser specification is estimated by using Ordinary Least Squares, and marginal effects of foreign and internal remittances on various expenditure categories are subsequently obtained. However, these estimates are not considered reliable if there are large numbers of zero values in the dependent variable. This can happen if spending on certain items is infrequent. Some households may not purchase any durable items during a given year. Likewise, 
spending on some items may not be required. For example, households with no school-going children may not spend on education. For such censored datasets, Tobit is considered to be more appropriate. Three consumption categories: education, recreation and durables show nonnegligible number of zero values, with $34 \%, 57 \%$ and $33 \%$ zero values respectively, and are therefore examined using Tobit specifications. Other expenditure categories contain less than one percent zero values, and are analyzed using OLS.

\subsection{Propensity Score Matching (PSM) models}

Households receiving remittances often differ from non receiving households in such important aspects as financial wherewithal, education, skills and demographic characteristics. Regressionbased estimation of remittances' impacts on expenditures may therefore be prone to selection bias in such non experimental situations. The observed outcome (called factual or post treatment outcome) needs to be compared with the outcome that would occur had the households not received remittances (counterfactual outcome).

One way of achieving this is by applying a matching algorithm. Matching methods assume the selection into treatment group to be based on the households' observable characteristics, implying that households in the treatment and non treatment groups can be matched with respect to those characteristics. However, matching requires identification of comparable groups of households with similar characteristics. This can be done using Propensity Score Matching (PSM) by constructing a summary variable for observable household characteristics, called the “propensity score” (Rosenbaum and Rubin, 1983; 1985).

PSM is essentially a weighting scheme that matches treated and non treated households by comparing the conditional probabilities of receiving remittance based on a set of covariates of the observable characteristics. The probabilities are obtained by using either the Probit or Logit 
models. As for both types of households, only one state (receipt or non receipt) can be observed at a given moment (Holland, 1986). Therefore, average treatment effect on the treated (ATT) is calculated as the mean effect of the paired households.

Three matching techniques: Nearest Neighbour (NN), Radius and Kernel are employed in the study. For Kernel matching, Gaussian Kernel estimator is employed with a default bandwidth of 0.06 as well as a lower bandwidth of 0.01 to obtain unbiased estimates. The PSM estimations are carried out using Stata’s psmatch2 module (Leuven and Sianesi, 2012).

Table A12 and Figure A1 to Figure A4 show tests for the requisite assumptions. Figures A1 and A2 show density distributions for the estimated propensity scores for receiving and nonreceiving households, while Figure A3 to Figure A4 show pre- and post-matching bias reduction. The common support and balancing conditions are mostly satisfied. There is sufficient overlapping in the propensity scores of recipient and non-recipient households,and a substantial reduction in the median absolute standardized bias after matching. The remaining bias is less than $10 \%$ in all the estimations, lower than the $20 \%$ figure suggested by Rosenbaum and Rubin (1985). Moreover, the post-matching pseudo- $\mathrm{R}^{2}$ value is considerably lower and the likelihood ratio is insignificant, implying the absence of any systematic difference in distribution of covariates between the treated and control groups. The characteristics of the constructed groups of recipient and non-recipient households can therefore be considered comparable.

The conditional independence assumption is tested through the Rosenbaum bounds test $(\text { Rosenbaum 2002) })^{2}$. The test indicates that the odds of unobservable characteristics influencing the average treatment effects can not be satisfactorily rejected (Tables 13A and 14A) ${ }^{3}$. The assumed odd ratios for ATT sensitivity are invariably less than 2, the critical value suggested by 
Duvendack and Palmer-Jones (2012). The Wilcoxon rank test p-value is greater than 0.05 in several estimations and the Hodges-Lehmann confidence interval encompasses zero.

This suggests that the assignment process is vulnerable to unobserved variables and the inferences made on the basis of these results are therefore not robust to hidden bias.

\section{Findings}

\subsection{Working Leser estimations}

Tables 5 and 6 present the results of OLS and Tobit estimations of the Working Leser specifications and marginal effects for the shares of various household expenditures. The relationship between foreign remittances and expenditure is found to be statistically insignificant in five out of eight spending categories (Table 5). Only education, housing and utilities, and recreation spending show a significant association with foreign remittances, the latter two with a negative sign suggesting proportionally lower housing and recreation budgets among households receiving foreign remittances. Education spending among recipient households is $4.23 \%$ compared with $3.43 \%$ in non-recipient households (Table 6), implying a substantial 23\% difference. Among other variables included in the model, most demographic variables exhibit a significant association with household expenditures. For example, larger households have a significantly higher expenditure share dedicated to food and consumer items, and lower spending on health, housing, recreation and durables. Household spending on food, health and durables increases and that on education decreases with its head's age. Likewise, the share of education spending increases with head's education as well as the number of literates at home. Female heads appear to spend proportionally more on education and consumer goods compared with male heads. 
Table 5. Remittances and household consumption (OLS and Tobit estimations)

\begin{tabular}{|c|c|c|c|c|c|c|c|c|}
\hline VARIABLES & Food & Health & Education & Housing & Recreation & Other & $\begin{array}{l}\text { Consumer } \\
\text { Good }\end{array}$ & Durables \\
\hline $\begin{array}{l}\text { Total } \\
\text { expenditure }\end{array}$ & $\begin{array}{l}-3.357 * * * \\
(0.657)\end{array}$ & $\begin{array}{l}0.219 \\
(0.238)\end{array}$ & $\begin{array}{l}1.687 * * *_{-} \\
(0.287)\end{array}$ & $\begin{array}{l}-2.031^{*} \\
(1.058)\end{array}$ & $\begin{array}{l}-0.212 * * * \\
(0.030)\end{array}$ & $\begin{array}{l}4.287 * * * \\
(0.502)\end{array}$ & $\begin{array}{l}-3.477 * * * \\
(0.167)\end{array}$ & $\begin{array}{l}2.883 * * * \\
(0.397)\end{array}$ \\
\hline $\begin{array}{l}\text { Foreign } \\
\text { remittances }\end{array}$ & $\begin{array}{l}0.229 \\
(0.631)\end{array}$ & $\begin{array}{l}0.211 \\
(0.259)\end{array}$ & $\begin{array}{l}0.797 * \\
(0.419)\end{array}$ & $\begin{array}{l}-1.146^{*} \\
(0.630)\end{array}$ & $\begin{array}{l}-0.150 * * * \\
(0.038)\end{array}$ & $\begin{array}{l}-0.427 \\
(0.612)\end{array}$ & $\begin{array}{l}0.200 \\
(0.229)\end{array}$ & $\begin{array}{l}0.286 \\
(0.422)\end{array}$ \\
\hline $\begin{array}{l}\text { Domestic } \\
\text { remittances }\end{array}$ & $\begin{array}{l}-1.328 * * \\
(0.604)\end{array}$ & $\begin{array}{l}1.126 * * * \\
(0.312)\end{array}$ & $\begin{array}{l}0.483 \\
(0.302)\end{array}$ & $\begin{array}{l}-0.408 \\
(0.513)\end{array}$ & $\begin{array}{l}-0.115^{* * * *} \\
(0.032)\end{array}$ & $\begin{array}{l}-0.302 \\
(0.433)\end{array}$ & $\begin{array}{l}0.216 \\
(0.193)\end{array}$ & $\begin{array}{l}0.327 \\
(0.304)\end{array}$ \\
\hline Asset index & $\begin{array}{l}-1.104 * * * \\
(0.133)\end{array}$ & $\begin{array}{l}-0.134 * * * \\
(0.045)\end{array}$ & $\begin{array}{l}0.213 * * * \\
(0.053)\end{array}$ & $\begin{array}{l}0.982 * * * \\
(0.155)\end{array}$ & $\begin{array}{l}0.0986^{* * * *} \\
(0.008)\end{array}$ & $\begin{array}{l}-0.229 * * \\
(0.099)\end{array}$ & $\begin{array}{l}0.208 * * * \\
(0.042)\end{array}$ & $\begin{array}{l}-0.034 \\
(0.050)\end{array}$ \\
\hline $\begin{array}{l}\text { Household } \\
\text { size }\end{array}$ & $\begin{array}{l}1.002 * * * \\
(0.087)\end{array}$ & $\begin{array}{l}-0.0605^{*} \\
(0.034)\end{array}$ & $\begin{array}{l}-0.027 \\
(0.035)\end{array}$ & $\begin{array}{l}-0.861 * * * * \\
(0.120)\end{array}$ & $\begin{array}{l}-0.022 * * * \\
(0.006)\end{array}$ & $\begin{array}{l}-0.22 * * * \\
(0.073)\end{array}$ & $\begin{array}{l}0.327 * * * \\
(0.029)\end{array}$ & $\begin{array}{l}-0.14 * * * \\
(0.047)\end{array}$ \\
\hline $\begin{array}{l}\text { Dependency } \\
\text { ratio }\end{array}$ & $\begin{array}{l}-3.171 * * * \\
(0.938)\end{array}$ & $\begin{array}{l}0.508 \\
(0.402)\end{array}$ & $\begin{array}{l}2.603 * * * \\
(0.385)\end{array}$ & $\begin{array}{l}2.617 * * \\
(1.119)\end{array}$ & $\begin{array}{l}-0.013 \\
(0.071)\end{array}$ & $\begin{array}{l}-0.882 \\
(0.719)\end{array}$ & $\begin{array}{l}0.118 \\
(0.300)\end{array}$ & $\begin{array}{l}-1.78 * * * \\
(0.518)\end{array}$ \\
\hline Schooling 18 & $\begin{array}{l}-0.551 * * * \\
(0.154)\end{array}$ & $\begin{array}{l}0.087 \\
(0.058)\end{array}$ & $\begin{array}{l}0.141^{* *} \\
(0.067)\end{array}$ & $\begin{array}{l}0.443 * * * \\
(0.152)\end{array}$ & $\begin{array}{l}0.0187 * \\
(0.010)\end{array}$ & $\begin{array}{l}-0.194^{*} \\
(0.115)\end{array}$ & $\begin{array}{l}0.198 * * * \\
(0.052)\end{array}$ & $\begin{array}{l}-0.142 * \\
(0.083)\end{array}$ \\
\hline Sex of head & $\begin{array}{l}1.202 \\
(0.745)\end{array}$ & $\begin{array}{l}-0.498 \\
(0.371)\end{array}$ & $\begin{array}{l}1.720 * * * \\
(0.533)\end{array}$ & $\begin{array}{l}-0.582 \\
(0.729)\end{array}$ & $\begin{array}{l}0.030 \\
(0.051)\end{array}$ & $\begin{array}{l}-2.67 * * * \\
(0.665)\end{array}$ & $\begin{array}{l}0.641 * * \\
(0.254)\end{array}$ & $\begin{array}{l}0.154 \\
(0.519)\end{array}$ \\
\hline Age of head & $\begin{array}{l}-0.220 * * * \\
(0.069)\end{array}$ & $\begin{array}{l}-0.115 * * \\
(0.050)\end{array}$ & $\begin{array}{l}0.299 * * * \\
(0.037)\end{array}$ & $\begin{array}{l}-0.017 \\
(0.059)\end{array}$ & $\begin{array}{l}0.004 \\
(0.004)\end{array}$ & $\begin{array}{r}0.0947 * \\
(0.050)\end{array}$ & $\begin{array}{l}0.030 \\
(0.021)\end{array}$ & $\begin{array}{l}-0.074 * * \\
(0.034)\end{array}$ \\
\hline $\begin{array}{l}\text { Age of head } \\
\text { squared }\end{array}$ & $\begin{array}{l}0.0027 * * * \\
(0.001)\end{array}$ & $\begin{array}{l}0.0011 * * \\
(0.000)\end{array}$ & $\begin{array}{l}-0.0032 * * * \\
(0.000)\end{array}$ & $\begin{array}{l}0.000 \\
(0.001)\end{array}$ & $\begin{array}{l}0.000 \\
(0.000)\end{array}$ & $\begin{array}{l}-0.0009^{*} \\
(0.001)\end{array}$ & $\begin{array}{l}-0.00037 * \\
(0.000)\end{array}$ & $\begin{array}{l}0.00058 * \\
(0.000)\end{array}$ \\
\hline Marital status & $\begin{array}{l}-0.159 \\
(0.562)\end{array}$ & $\begin{array}{l}-0.519 \\
(0.433)\end{array}$ & $\begin{array}{l}0.333 \\
(0.264)\end{array}$ & $\begin{array}{l}-1.789 * * * \\
(0.622)\end{array}$ & $\begin{array}{l}-0.004 \\
(0.035)\end{array}$ & $\begin{array}{l}0.935^{* *} \\
(0.422)\end{array}$ & $\begin{array}{l}0.575^{* * * *} \\
(0.168)\end{array}$ & $\begin{array}{l}0.628 * * \\
(0.254)\end{array}$ \\
\hline $\begin{array}{l}\text { Education } \\
\text { head }\end{array}$ & $\begin{array}{l}-0.074 \\
(0.141)\end{array}$ & $\begin{array}{l}-0.129 * \\
(0.070)\end{array}$ & $\begin{array}{l}0.211 * * * \\
(0.058)\end{array}$ & $\begin{array}{l}0.072 \\
(0.138)\end{array}$ & $\begin{array}{l}0.0278 * * * \\
(0.008)\end{array}$ & $\begin{array}{l}0.202 * * \\
(0.102)\end{array}$ & $\begin{array}{l}0.018 \\
(0.044)\end{array}$ & $\begin{array}{l}-0.33 * * * \\
(0.072)\end{array}$ \\
\hline Work head & $\begin{array}{l}2.752 * * * \\
(0.481)\end{array}$ & $\begin{array}{l}0.055 \\
(0.199)\end{array}$ & $\begin{array}{l}-0.195 \\
(0.334)\end{array}$ & $\begin{array}{l}-1.905^{* * * *} \\
(0.527)\end{array}$ & $\begin{array}{l}0.009 \\
(0.030)\end{array}$ & $\begin{array}{l}-0.652 \\
(0.468)\end{array}$ & $\begin{array}{l}-0.081 \\
(0.168)\end{array}$ & $\begin{array}{l}0.017 \\
(0.261)\end{array}$ \\
\hline $\begin{array}{l}\text { Local } \\
\text { Economic } \\
\text { condition }\end{array}$ & $\begin{array}{l}1.506 * * * \\
(0.244)\end{array}$ & $\begin{array}{l}-0.480^{* * *} \\
(0.112)\end{array}$ & $\begin{array}{l}-0.280 * * \\
(0.113)\end{array}$ & $\begin{array}{l}-1.669 * * * \\
(0.301)\end{array}$ & $\begin{array}{l}0.023 \\
(0.019)\end{array}$ & $\begin{array}{l}0.522 * * * \\
(0.189)\end{array}$ & $\begin{array}{l}0.135 \\
(0.088)\end{array}$ & $\begin{array}{l}0.242 * \\
(0.141)\end{array}$ \\
\hline $\begin{array}{l}\mathrm{HH} \text { economic } \\
\text { condition }\end{array}$ & $\begin{array}{l}-0.429 \\
(0.310)\end{array}$ & $\begin{array}{l}-0.056 \\
(0.134)\end{array}$ & $\begin{array}{l}0.134 \\
(0.136)\end{array}$ & $\begin{array}{l}-0.371 \\
(0.296)\end{array}$ & $\begin{array}{l}-0.015 \\
(0.021)\end{array}$ & $\begin{array}{l}0.177 \\
(0.196)\end{array}$ & $\begin{array}{l}0.482 * * * \\
(0.105)\end{array}$ & $\begin{array}{l}0.079 \\
(0.151)\end{array}$ \\
\hline Region & $\begin{array}{l}-5.043 * * * \\
(0.493)\end{array}$ & $\begin{array}{l}-0.548 * * * \\
(0.165)\end{array}$ & $\begin{array}{l}0.706 * * * \\
(0.203)\end{array}$ & $\begin{array}{l}7.317 * * * \\
(0.531)\end{array}$ & $\begin{array}{l}0.431 * * * \\
(0.035)\end{array}$ & $\begin{array}{l}-1.51 * * * \\
(0.346)\end{array}$ & $\begin{array}{l}-0.488 * * * \\
(0.186)\end{array}$ & $\begin{array}{l}-0.87 * * * \\
(0.231)\end{array}$ \\
\hline Province & $\begin{array}{l}-0.570 \\
(0.425)\end{array}$ & $\begin{array}{l}0.097 \\
(0.136)\end{array}$ & $\begin{array}{l}-0.669 * * * \\
(0.166)\end{array}$ & $\begin{array}{l}1.538 * * * \\
(0.499)\end{array}$ & $\begin{array}{l}0.285^{* * * *} \\
(0.031)\end{array}$ & $\begin{array}{l}1.341 * * * \\
(0.304)\end{array}$ & $\begin{array}{l}-0.889 * * * \\
(0.170)\end{array}$ & $\begin{array}{l}-1.13 * * * \\
(0.149)\end{array}$ \\
\hline Constant & $\begin{array}{l}88.33 * * * \\
(7.222)\end{array}$ & $\begin{array}{l}4.787 * * \\
(2.007)\end{array}$ & $\begin{array}{l}-27.13 * * * \\
(3.233)\end{array}$ & $\begin{array}{l}47.81 * * * \\
(11.610)\end{array}$ & $\begin{array}{l}2.074 * * * \\
(0.348)\end{array}$ & $\begin{array}{l}-36.8 * * * \\
(5.49)\end{array}$ & $\begin{array}{l}48.58 * * * \\
(1.887)\end{array}$ & $\begin{array}{l}-27.7 * * * \\
(4.244)\end{array}$ \\
\hline $\begin{array}{l}\text { Observations } \\
\text { R-squared }\end{array}$ & $\begin{array}{l}8671 \\
0.295\end{array}$ & $\begin{array}{l}8671 \\
0.042\end{array}$ & 8671 & $\begin{array}{l}8671 \\
0.284\end{array}$ & 8671 & $\begin{array}{l}8671 \\
0.097\end{array}$ & $\begin{array}{l}8671 \\
0.221\end{array}$ & 8671 \\
\hline Sigma & & & $\begin{array}{l}4.923 * * * \\
-0.192 \\
\end{array}$ & & $\begin{array}{l}0.680 * * * \\
-0.033 \\
\end{array}$ & & & $\begin{array}{l}5.225 * * * \\
-0.254 \\
\end{array}$ \\
\hline
\end{tabular}

Note: Standard errors in parentheses. Significance level: *** $\mathrm{p}<0.01, * * \mathrm{p}<0.05, * \mathrm{p}<0.1$

The share of food spending decreases with household's total spending and asset ownership.

Local economic conditions also seem to affect the household's consumption pattern, as 
households which report a better local economic situation in the area compared to the previous year show proportionally higher spending on nutrition.

The receipt of domestic remittances is significantly associated with three expenditure categories, two of which are statistically significant at the $1 \%$ level (Table 5). Recipient households have lower food and recreation budget shares and higher health spending. This reflects domestic remittance receiving households lower average income (average annual income being Rs. 172,900 as compared to Rs. 223,309 for non-recipient households'). The share of health spending among recipients of domestic transfers is $36 \%$ higher $(4.25 \%$ vs $3.12 \%)$ than nonrecipient households (Table 6).

Table 6. Marginal Budget Shares by Access to remittances

\begin{tabular}{lllllll}
\hline Consumption indicators & $\begin{array}{l}\text { HH with no } \\
\text { Foreign } \\
\text { Remittances }\end{array}$ & $\begin{array}{l}\text { HH with } \\
\text { Foreign } \\
\text { Remittances }\end{array}$ & z -stat & $\begin{array}{l}\text { HH with no } \\
\text { Domestic } \\
\text { Remittances }\end{array}$ & $\begin{array}{l}\text { HH with } \\
\text { Domestic } \\
\text { Remittances }\end{array}$ & z-stat \\
\hline \hline Food & 38.87 & 39.10 & 0.36 & 39.00 & 37.67 & -2.20 \\
Education & 3.43 & 4.23 & 1.90 & 3.43 & 3.92 & 1.60 \\
Health & 3.21 & 3.42 & 0.81 & 3.12 & 4.25 & 3.61 \\
Housing and Utilities & 27.20 & 26.05 & -1.82 & 27.17 & 26.76 & -0.80 \\
Recreation & 0.53 & 0.38 & -3.91 & 0.53 & 0.42 & -3.59 \\
Consumer non-durables & 10.72 & 10.92 & 0.87 & 10.71 & 10.92 & 1.12 \\
Miscellaneous & 14.08 & 13.65 & -0.70 & 14.08 & 13.78 & -0.70 \\
Durables & 1.97 & 2.26 & 0.68 & 1.96 & 2.28 & 1.08 \\
\hline \hline
\end{tabular}

Shares of food and recreation spending show less substantial difference, the two being lower by $3.4 \%$ and $21 \%$ respectively.

The consumption patterns of households living below the poverty line appear to be significantly different than those of their non-recipient counterparts (Table 7). 
Table 7. Marginal Budget Shares - Poor households

\begin{tabular}{lllllll}
\hline \hline Consumption indicators & $\begin{array}{l}\text { HH with no } \\
\text { Foreign } \\
\text { Remittances }\end{array}$ & $\begin{array}{l}\text { HH with } \\
\text { Foreign } \\
\text { Remittances }\end{array}$ & z -stat & $\begin{array}{l}\text { HH with no } \\
\text { Domestic } \\
\text { Remittances }\end{array}$ & $\begin{array}{l}\text { HH with } \\
\text { Domestic } \\
\text { Remittances }\end{array}$ & z -stat \\
\hline \hline Food & 42.01 & 46.69 & 1.82 & 42.14 & 41.20 & -0.77 \\
Education & 1.97 & 1.13 & -1.97 & 1.92 & 2.49 & 1.60 \\
Health & 3.68 & 3.98 & 0.56 & 3.68 & 3.64 & -0.12 \\
Housing and Utilities & 26.41 & 21.53 & -3.58 & 26.24 & 27.69 & 1.42 \\
Recreation & 0.26 & 0.03 & -2.08 & 0.27 & 0.07 & -4.17 \\
Consumer non-durables & 12.92 & 12.49 & -0.55 & 12.89 & 13.13 & 0.46 \\
Miscellaneous & 12.05 & 12.08 & 0.02 & 12.14 & 11.09 & -1.70 \\
Durables & 0.69 & 2.06 & 1.04 & 0.71 & 0.67 & -0.15 \\
\hline \hline
\end{tabular}

Poor foreign remittance receiving households spend proportionally more on food and less on education, housing and recreation compared with non-recipient poor households'. Food spending is $11.1 \%$ higher, while that on education and housing is $42.6 \%$ and $18.5 \%$ lower respectively. In contrast, non-poor recipient households appear to diverge little from their non-recipient counterparts in their consumption patterns (Table 8).

Table 8. Marginal Budget Shares - Non-poor households

\begin{tabular}{lllllll}
\hline Consumption indicators & $\begin{array}{l}\text { HH with no } \\
\text { Foreign } \\
\text { Remittances }\end{array}$ & $\begin{array}{l}\text { HH with } \\
\text { Foreign } \\
\text { Remittances }\end{array}$ & z -stat & $\begin{array}{l}\text { HH with no } \\
\text { Domestic } \\
\text { Remittances }\end{array}$ & $\begin{array}{l}\text { HH with } \\
\text { Domestic } \\
\text { Remittances }\end{array}$ & z -stat \\
\hline \hline Food & 38.24 & 38.20 & -0.07 & 38.38 & 36.79 & -2.36 \\
Education & 3.73 & 4.60 & 1.99 & 3.74 & 4.23 & 1.40 \\
Health & 3.11 & 3.32 & 0.74 & 3.01 & 4.36 & 3.83 \\
Housingand Utilities & 27.34 & 26.53 & -1.25 & 27.35 & 26.68 & -1.19 \\
Recreation & 0.58 & 0.45 & -3.29 & 0.58 & 0.49 & -2.64 \\
Consumer non-durables & 10.27 & 10.51 & 0.98 & 10.27 & 10.51 & 1.24 \\
Miscellaneous & 14.49 & 13.97 & -0.80 & 14.46 & 14.38 & -0.17 \\
Durables & 2.23 & 2.43 & 0.46 & 2.21 & 2.56 & 1.00 \\
\hline \hline
\end{tabular}

Unlike poor recipients, non-poor recipients seem to allocate a higher budget share to education.

The behavior of poor recipients of foreign remittances differs remarkably from that of poor 
recipients of domestic transfers whose education and housing spending is significantly different than that of their non receiving counterparts. The expenditure patterns of non-poor households receiving transfers from within the country mostly resemble those of an average receiving household.

\subsection{PSM estimations}

Table 9 gives the results of the Propensity Score Matching estimations for foreign and domestic remittances. Results of Kernel matching, Radius matching and Nearest Neighbour matching are similar. Both foreign and domestic remittance receiving households appear to be significantly different from their non-recipient counterparts in four out of eight categories. Foreign remittance receiving households spend proportionally more on education, consumer goods, recreation and durables.

However, the differences are robust only in the case of education spending. The share of education spending among recipients is substantially higher than their comparable non-recipient counterparts. This finding is similar to the one found using the Working Leser model.

The difference in Average Treatment Effect in Treatment (ATT) between treated and control group is substantially smaller than the unmatched difference. For the aforementioned four categories, the corresponding unmatched and ATT differences are 2.76 and 1.58 for education, 0.53 and 0.39 for consumer non-durables, 0.07 and 0.08 for recreation, and 1.4 and 0.62 for durable goods respectively ${ }^{4}$. 
Table 9. Remittances and household budget shares (Propensity Score Matching)

\begin{tabular}{|c|c|c|c|c|}
\hline Consumption indicators & $\mathbf{N N}$ & Kernel & Kernel (b.w 0.01) & Radius \\
\hline \multicolumn{5}{|l|}{ Foreign Remittances } \\
\hline Food & $\begin{array}{l}-0.094 \\
(0.848)\end{array}$ & $\begin{array}{l}-0.567 \\
(0.670)\end{array}$ & $\begin{array}{l}-0.336 \\
(0.699)\end{array}$ & $\begin{array}{l}-0.391 \\
(0.681)\end{array}$ \\
\hline Health & $\begin{array}{l}0.029 \\
(0.273)\end{array}$ & $\begin{array}{l}-0.027 \\
(0.206)\end{array}$ & $\begin{array}{l}-0.046 \\
(0.217)\end{array}$ & $\begin{array}{l}-0.041 \\
(0.210\end{array}$ \\
\hline Education & $\begin{array}{l}1.002 * * \\
(0.505)\end{array}$ & $\begin{array}{l}1.583^{* * *} * \\
(0.423)\end{array}$ & $\begin{array}{l}1.462 * * * \\
(0.430)\end{array}$ & $\begin{array}{l}1.490 * * * \\
(0.426)\end{array}$ \\
\hline Housingand Utilities & $\begin{array}{l}-0.514 \\
(0.754)\end{array}$ & $\begin{array}{l}-0.762 \\
(0.608)\end{array}$ & $\begin{array}{l}-0.563 \\
(0.635)\end{array}$ & $\begin{array}{l}-0.585 \\
(0.618)\end{array}$ \\
\hline Consumer non-durables & $\begin{array}{l}-0.484 * \\
(0.264)\end{array}$ & $\begin{array}{l}-0.391 * \\
(0.211)\end{array}$ & $\begin{array}{l}-0.346 \\
(0.221)\end{array}$ & $\begin{array}{l}-0.324 \\
(0.215)\end{array}$ \\
\hline Recreation & $\begin{array}{l}-0.032 \\
(0.053)\end{array}$ & $\begin{array}{l}-0.082 * \\
(0.048)\end{array}$ & $\begin{array}{l}-0.085^{*} \\
(0.050)\end{array}$ & $\begin{array}{l}-0.086^{*} \\
(0.049)\end{array}$ \\
\hline Others & $\begin{array}{l}-0.462 \\
(0.640)\end{array}$ & $\begin{array}{l}-0.370 \\
(0.531)\end{array}$ & $\begin{array}{l}-0.55 \\
(0.551)\end{array}$ & $\begin{array}{l}-0.606 \\
(0.538)\end{array}$ \\
\hline Durables & $\begin{array}{l}0.556 \\
(0.421)\end{array}$ & $\begin{array}{l}0.616 * \\
(0.327)\end{array}$ & $\begin{array}{l}0.468 \\
(0.336)\end{array}$ & $\begin{array}{l}0.543 * \\
(0.331)\end{array}$ \\
\hline
\end{tabular}

Domestic Remittances

\begin{tabular}{lllll}
\hline Food & -0.948 & -0.490 & -0.639 & -0.620 \\
& $(0.692)$ & $(0.526)$ & $(0.537)$ & $(0.532)$ \\
\hline Health & $1.148 * * *$ & $1.060 * *$ & $0.993 * * *$ & $1.014 * * *$ \\
& $(0.244)$ & $(0.218)$ & $(0.221)$ & $(0.219)$ \\
\hline Education & $0.657 *$ & $0.547 *$ & $0.503 *$ & $0.552^{*}$ \\
& $(0.348)$ & $(0.287)$ & $(0.291)$ & $(0.289)$ \\
\hline Housingand Utilities & -0.885 & $-0.964 * *$ & $-0.832 *$ & $-0.849 *$ \\
& $(0.616)$ & $(0.472)$ & $(0.483)$ & $(0.477)$ \\
\hline Consumer non-durables & 0.093 & 0.210 & 0.183 & 0.173 \\
& $(0.220)$ & $(0.175)$ & $(0.178)$ & $(0.177)$ \\
\hline Recreation & $-0.106 * * *$ & $-0.128 * * *$ & $-0.093 * * *$ & $-0.102 * * *$ \\
& $(0.038)$ & $(0.030)$ & $(0.031)$ & $(0.031)$ \\
\hline Others & -0.358 & -0.550 & -0.480 & -0.511 \\
& $(0.490)$ & $(0.383)$ & $(0.390)$ & $(0.386)$ \\
\hline Durables & 0.399 & 0.316 & 0.365 & 0.342 \\
& $(0.314)$ & $(0.251)$ & $(0.255)$ & $(0.253)$ \\
\hline
\end{tabular}

Note: Observations lying the common support zone are discarded. Standard errors in parentheses. Significance level: $* * *$ p $<0.01$, $* * \mathrm{p}<0.05, * \mathrm{p}<0.1$

Unlike households that receive international transfers, recipients of domestic transfers seem to allocate a significantly high budget share to healthcare. Recipient households' share of healthcare spending is $30-36 \%$ higher than their non-recipient counterparts. This is in line with 
the results of the Working Leser model. In addition to health, budget shares of recreation, education and housing and utilities also significantly differ, with recipient households spending proportionally more on education and less on the other two categories.

As before, poor recipient households allocate their budgets substantially differently compared with the non-recipient households ${ }^{5}$. Those receiving international transfers allocate a higher share of annual expenditure to food and a lower share to housing and utilities. Likewise, the budget shares of education and housing of domestic transfers receiving households are significantly higher than those of non-recipient households.

\section{Discussion}

Our findings indicate that both foreign and domestic remittance receiving households have a greater proclivity for human capital accumulation. Recipients of foreign remittances spend proportionally more on education compared with the non-recipient households. This supports the view that migration from a developing to a developed country or from villages to urban centers brings greater realization of high returns to human capital among migrants and their households back home. Similarly, households receiving domestic transfers allocate a substantially greater share of the household budget to healthcare expenditures. This increase in health spending among the recipient households is probably meant for out of pocket health expenditures. In developing countries like Pakistan, public health care services are generally inadequate and consequently, well-to-do households often resort to private service providers for healthcare provision.

The difference between consumption patterns of households receiving international and domestic remittances may lie in the economic situation of those households. The amount of international 
remittances, especially sent by migrants settled in North America or Europe or the workers that have resided for a long time in the Gulf states, are usually higher and often go to more prosperous households. Better financial wherewithal of these households implies that basic necessities are already satisfied and additional income source in the form of receipts from abroad could be allocated to education. Domestic remittance receiving households, on the other hand, are on average poorer, and might not be in a position to allocate sufficient funds to healthcare prior to receiving money from the migrant. This also corroborates the argument of Clément (2011) in the context of Tajikistan that improving health outcomes is a short-term priority that comes before more long-term investments such as education or agriculture.

The finding that spending patterns of poor recipient households differ from the rest of the population also supports the argument that differences in consumption preferences among remittance receiving and non-receiving households arise partly due to differences in the economic conditions of the two groups of households. A greater share of the household budget allocated to food among low income households as opposed to the spending among the non-poor which is similar across the recipient and non-recipient households supports Engel's law. This finding is also reported in studies on other developing countries, such as Adams and Cuecuecha (2010b), Castaldo and Reilly (2007) and Tabuga (2007).

The varying consumption patterns of recipient and non-recipient households indicate that the fungibility of migrant remittances depends on the resources available to the receiving households, and the propensity to spend on different consumption items resulting from migrant remittances corresponds to the household's level of human development. 
The fact that the consumption patterns of remittance receiving and non-receiving households differ substantially and that shares of education and healthcare spending are higher among recipient households suggests that the recipients perceive remittances as a temporary source of income which needs to be spent differently than the households' permanent income sources. This finding can be understood in light of the fact that much of the international migration from Pakistan is to the oil-rich states of the Persian Gulf which do not allow a permanent migration of the international labour force. Given the temporary nature of Pakistani overseas workers, a greater portion of the money remitted is used to improve the receiving households' health and education endowment. Remittances from domestic migrants are likewise perceived as temporary even though internal migration in Pakistan is often of a permanent nature. Internal migrants, while initially maintaining kinship ties with their home towns or villages, gradually settle down in the new environment. The process of remittance decay therefore sets in.

\section{Robustness and sensitivity checks}

An over all good balancing does not always imply joint balancing of all the covariates which can lead to less bias reduction. This problem can be tackled by integrating covariate balance into the weight function employed to adjust the control units (Hainmueller, 2012). This method of 'Entropy balancing' can significantly improve the quality of covariate balance and allows better use of information present in the data. The method preprocesses data by adjusting weights to include the selected covariates on the known moments of the covariate distribution, thereby obtaining exact covariate balance. Table 10 gives the results of Entropy balancing for the two types of remittances. 
Table 10. Remittances and household consumption (Entropy balancing)

\begin{tabular}{|c|c|c|c|c|c|c|c|c|}
\hline & Food & Health & Education & $\begin{array}{l}\text { Housing } \\
\text { and } \\
\text { Utilities }\end{array}$ & $\begin{array}{l}\text { Consumer } \\
\text { non-durables }\end{array}$ & Recreation & Others & Durables \\
\hline $\begin{array}{l}\text { Foreign } \\
\text { Remittances }\end{array}$ & $\begin{array}{l}-0.145 \\
(0.587)\end{array}$ & $\begin{array}{l}0.059 \\
(0.206)\end{array}$ & $\begin{array}{l}1.125^{* *} \\
(0.451)\end{array}$ & $\begin{array}{l}-1.024^{*} \\
(0.533)\end{array}$ & $\begin{array}{l}-0.298 \\
(0.204)\end{array}$ & $\begin{array}{l}-0.087 * * \\
(0.042)\end{array}$ & $\begin{array}{l}-0.318 \\
(0.523)\end{array}$ & $\begin{array}{l}0.687 * \\
(0.387)\end{array}$ \\
\hline $\begin{array}{l}\text { Number of } \\
\text { households }\end{array}$ & 8671 & 8671 & 8671 & 8671 & 8671 & 8671 & 8671 & 8671 \\
\hline $\begin{array}{l}\text { Domestic } \\
\text { Remittances }\end{array}$ & $\begin{array}{l}-0.768^{*} \\
(0.461)\end{array}$ & $\begin{array}{l}1.010 * * * \\
(0.210)\end{array}$ & $\begin{array}{l}0.560^{*} \\
(0.289)\end{array}$ & $\begin{array}{l}-0.779^{*} \\
(0.433)\end{array}$ & $\begin{array}{l}0.151 \\
(0.171)\end{array}$ & $\begin{array}{l}-0.097 * * * \\
(0.027)\end{array}$ & $\begin{array}{l}-0.398 \\
(0.380)\end{array}$ & $\begin{array}{l}0.320 \\
(0.255)\end{array}$ \\
\hline $\begin{array}{l}\text { Number of } \\
\text { households }\end{array}$ & 8671 & 8671 & 8671 & 8671 & 8671 & 8671 & 8671 & 8671 \\
\hline
\end{tabular}

Note: For entropy balancing, households without remittances are reweighted such that the means, variances and skewness of the control variables resemble those of households with remittances. Standard errors are given in parentheses. Significance level: $* * * \mathrm{p}<0.01, * * \mathrm{p}<0.05, * \mathrm{p}<0.1$

The estimations are carried out using Stata's ebalance package (Hainmueller and Xu, 2013). The results obtained are similar to the results from other matching methods. Foreign remittances still affect four out of eight household expenditure categories, and impact on the share of education spending remains the strongest. The significance of results for domestic remittances improves and the impact on the budget share of food also turns significant. Other categories retain their signs and significance.

\section{Concluding remarks}

This study examined consumption patterns of Pakistani households in the context of international and domestic remittances by using the representative 2010-2011 Pakistan Social and Living Standards Measurement survey. A number of conclusions can be drawn from the study:

First, although budget shares for several expenditure categories are similar across remittance receiving and non-receiving households, those for three rubrics are substantially different. Remittances, therefore, cannot be deemed as entirely fungible. Secondly, recipient households perceive remittances as a mainly temporary source of income and spend them on the household members' education and healthcare. The share of education and healthcare spending is 
significantly higher among recipient households. This positive impact of remittances on the household resources dedicated to human capital is in line with the findings of previous studies on developing countries such as Acosta et al. (2007), Adams and Cuecuecha (2010b), and highlights the beneficial effects of remittances. Third, findings do not support the assertion that remittances are spent on frivolous consumption, as there is no evidence in favour of remittances raising the share of the so-called 'unproductive expenditures' such as conspicuous spending on social ceremonies and status-oriented consumer products. There is even some weak evidence suggesting a higher share of spending on durable items (usually deemed more productive) among foreign remittance receiving households. Finally, the differences in consumption patterns owing to foreign and internal remittances may partly be due to varying income levels of the two sets of households. International remittance receiving households in Pakistan are on average more prosperous than domestic remittance recipients, and probably enjoy a different level of consumption satisfaction. In the same vein, differences in consumption patterns are also clearly visible among poor and non-poor recipients. This suggests that for poor households, remittances are part of the strategy to improve access to nutrition, whereas for the more well-to-do households, remittances are a means to accumulate human and physical capital. 


\section{References}

Acosta, P., Fajnzylber, P., \& Lopez, J. H. (2007).The impact of remittances on poverty and human capital: evidence from Latin American household surveys, (Vol. 4247), World Bank.

Adams, Richard H. Jr. (1998). Remittances, Investment and Rural Asset Accumulation in Pakistan.Economic Development and Cultural Change 47, 155-73.

Adams , R. H., \&Cuecuecha, A. (2010a). The economic impact of international remittances on poverty and household consumption and investment in Indonesia , (Vol.5433), World Bank.

Adams, Richard H. Jr. \&Cuecuecha, A. (2010b). Remittances, household expenditure and investment in Guatemala.World Development, 38(11), 1626-1641.

Adams, Richard H. Jr. (1991). The economic uses and impacts of international remittances in rural Egypt, Economic Development and Cultural Change, University of Chicago Press, 39(4), 695-722

Ahmed, V., Sugiyarto, G., \&Jha, S. (2010). Remittances and household Welfare: A case study of Pakistan, 194. Asian Development Bank.

Alderman, H. (1996).Saving and economic shocks in rural Pakistan. Journal of Development Economics 51, 343-365.

Amuedo-Dorantes, C., \&Pozo, S. (2011). New evidence on the role of remittances on healthcare expenditures by Mexican households'.Review of Economics of the Household, 9(1), 6998.

Athukorala, P. (1990). International contract migration and the reintegration of return migrants: The experience of Sri Lanka. International Migration Review, 323-346. 
Arif, G. M. (2009). Economic and social impacts of remittances on households' : The case of Pakistani migrants working in Saudi Arabia. Pakistan Institute of Development Economics.

Arif, G. M. (2005). Internal migration and household well-being: Myth or reality. Internal Labour Migration in Pakistan.Institute of Developing Economies, Japan External Trade Organisation, Chiba, Japan.

Becker, S. O., \&Ichino, A. (2002).Estimation of average treatment effects based on propensity scores.The stata journal, 2(4), 358-377.

Chami, R., Jahjah, S., \&Fullenkamp, C. (2003).Are immigrant remittance flows a source of capital for development.International Monetary Fund.

Clément, M. (2011). Remittances and household expenditure patterns in Tajikistan: A propensity score matching analysis. Asian Development Review, 28(2).

Chandavarkar, A. G. (1980). Use of migrants remittances in labor-exporting countries. Finance \& development, 17(2), 36 .

Cardona Sosa, L., \& Medina, C. (2006).Migration as a safety net and effects of remittances on household consumption: The case of Colombia (No. 414). Banco de la Republica de Colombia.

Castaldo, A., \& Reilly, B. (2007).Do migrant remittances affect the consumption patterns of Albanian households' .South-Eastern Europe Journal of Economics, 1(1), 25-54.

Deaton A., Muellbauer J. (1999). Economics and consumer behavior. Cambridge University Press, Cambridge.

Dehejia, R. H., \&Wahba, S. (2002). Propensity score-matching methods for non-experimental causal studies.The Review of Economics and Statistics, 84(1), 151-161. 
Diamond, A., \&Sekhon, J. S. (2013). Genetic matching for estimating causal effects: A general multivariate matching method for achieving balance in observational studies. Review of Economics and Statistics, 95(3), 932-945.

DiPrete, T. A., \&Gangl, M. (2004).Assessing bias in the estimation of causal effects: Rosenbaum bounds on matching estimators and instrumental variables estimation with imperfect instruments.Sociological methodology, 34(1), 271-310.

Durand, J., \& Massey, D. S. (1992). Mexican migration to the United States: a critical review. Latin American Research Review, 27(2), 3-42.

Durand, J., W. Kandel, E.A. Parrado and D.S. Massey.(1996). International migration and development in Mexican communities.Demography, 33(2): 249-264.

Duvendack, M., \& Palmer-Jones, R. (2012). High noon for microfinance impact evaluations: reinvestigating the evidence from Bangladesh. The Journal of Development Studies, 48(12), 1864-1880.

Gangl, M. (2004). RBOUNDS: Stata module to perform Rosenbaum sensitivity analysis for average treatment effects on the treated. Statistical Software Components.

Hainmueller, J. (2012). Entropy balancing for causal effects: A multivariate reweighting method to produce balanced samples in observational studies.,Political Analysis , 20 (1): 25-46.

Hainmueller, J., \& Xu, Y. (2013).Ebalance: A Stata package for entropy balancing. Journal of Statistical Software, 54(7).

Holland, P. (1986). Statistics and causal inference. Journal of the American Statistical Association 81(396), 945-960. 
Jimenez, M.A.C. (2009). Household development in Tlapanana: A comparative study between households' receiving remittances and households' not receiving remittances. Journal of Poverty, 13(3), 331-349.

Kifle, T. (2007). Do remittances encourage investment in education? Evidence from Eritrea.GEFAME Journal of African Studies, 4(1).

Lee, W. S. (2013). Propensity score matching and variations on the balancing test. Empirical economics, 44(1), 47-80.

Leser, C. E. V. (1963). Forms of Engel functions. Econometrica: Journal of the Econometric Society, 694-703.

Lechner, M. (1999).The effects of enterprise-related training in East Germany on individual employment and earnings. Annalesd' Economieet de Statistique, 97-128.

Lechner, M. (2002). Program heterogeneity and propensity score matching: An application to the evaluation of active labor market policies. Review of Economics and Statistics, 84(2), 205-220.

Leuven, E., \&Sianesi, B. (2012). PSMATCH2: Stata module to perform full Mahalanobis and propensity score matching, common support graphing, and covariate imbalance testing. Statistical Software Components.

Massey, D. S. et al., (1987). Return to Aztlan: The social process of international migration from Western Mexico, Berkeley,University of California Press.

McKenzie, D. J., \&Sasin, M. J. (2007). Migration, remittances, poverty, and human capital: conceptual and empirical challenges (Vol. 4272). World Bank Publications. 
Osili, U. O. (2004). Migrants and housing investments: Theory and evidence from Nigeria*. Economic Development and Cultural Change, 52(4), 821-849.

Rosenbaum, P.R. (2002) Observational Studies.2nd edition. New York: Springer.

Rosenbaum, P. R., \& Rubin, D. B. (1985). Constructing a control group using multivariate matched sampling methods that incorporate the propensity score. The American Statistician, 39(1), 33-38.

Rosenbaum, P. R., \& Rubin, D. B. (1983). The central role of the propensity score in observational studies for causal effects. Biometrika, 70(1), 41-55.

Russell, S. S., Jacobsen, K., \& Stanley, W. D. (1990).International migration and development in Sub-Saharan Africa (Vol. 2, No. 102).

Sianesi, B. (2004). An evaluation of the Swedish system of active labor market programs in the 1990s. Review of Economics and Statistics, 86(1), 133-155.

Tabuga, A. D. (2007). International remittances and household expenditures: The Philippine Case (No. DP 2007-18). Philippine Institute for Development Studies.

Taylor, J. E., \&Mora, J. (2006).Does migration reshape expenditures in rural households' ?: evidence from Mexico (Vol. 3842). World Bank Publications.

Woodruff, Christopher, and Rene M. Zenteno (2007). Migration networks and microenterprises in Mexico, Journal of Development Economics 82(2) ,509-528

Working, H. (1943).Statistical laws of family expenditure, Journal of the American Statistical Association, 38(221), 43-56.

Yang, D. (2005).International migration, human capital, and entrepreneurship: evidence from Philippine migrants exchange rate shocks (Vol. 3578). World Bank Publications. 


\section{Appendix}

Table A11. Items included in the asset index.

\begin{tabular}{llll}
\hline Assets & Comp1 & Assets & Comp1 \\
\hline Eigenvectors & \multicolumn{3}{l}{ Eigenvectors } \\
\hline Electric Iron & 0.2607 & Tractor & 0.0363 \\
\hline Electric Fan & 0.1887 & Mobile & 0.2137 \\
\hline SewingMachine & 0.1958 & Cookingrange & 0.1166 \\
\hline Radio & 0.0574 & Burner & 0.2380 \\
\hline Chair & 0.2334 & Washingmachine & 0.2708 \\
\hline Watch & 0.1971 & Phone & 0.2112 \\
\hline Television & 0.2507 & Electricity & 0.1597 \\
\hline VCP & 0.1203 & Cooking_fuel & 0.2401 \\
\hline Refrigerator & 0.2694 & Toilet & 0.1754 \\
\hline Air Cooler & 0.1361 & Numberofrooms & 0.1658 \\
\hline Air Conditioner & 0.1598 & House_ownership & -0.0303 \\
\hline Computer & 0.1743 & Roof & 0.2236 \\
\hline Bicycle & 0.0095 & Walls & 0.2204 \\
\hline Motorcycle & 0.1451 & Piped_water & 0.1409 \\
\hline Car & 0.1415 & & $\mathbf{7 . 3 8 3 2}$ \\
\hline Eigen values & & & $\mathbf{0 . 2 5 4 6}$ \\
\hline Explained Proportion ofvariance & & $\mathbf{0 . 2 5 4 6}$ \\
\hline Explained cumulative proportion of & & & \\
variance & & & \\
\hline
\end{tabular}

Figure A1. Density distributions for the estimated propensity scores for foreign remittance receiving and non-receiving households'

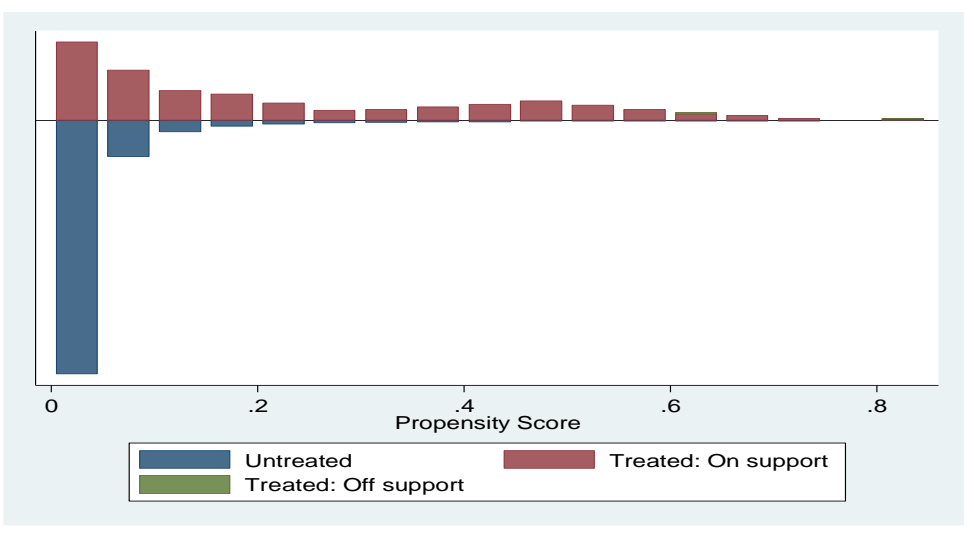


Figure A2. Density distributions for the estimated propensity scores for domestic remittance receiving and non-receiving households'

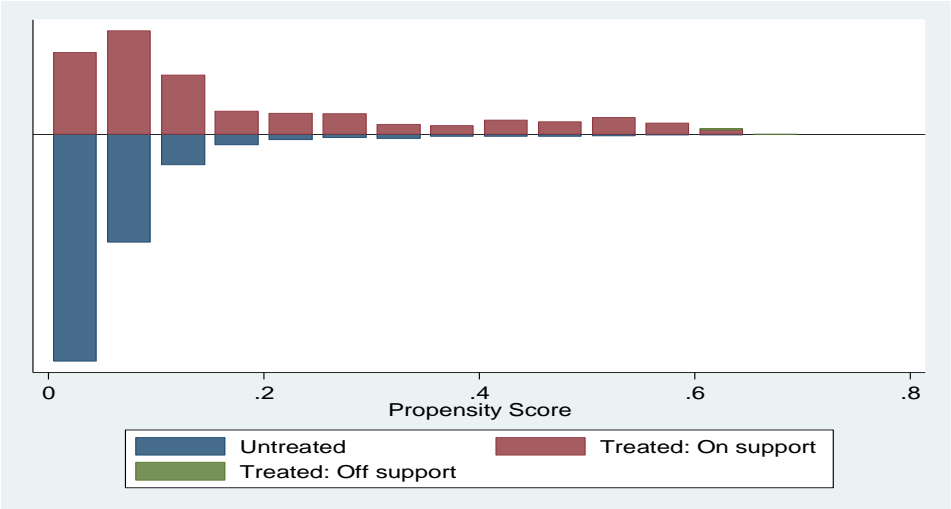

Figure A3. Pre- and post-matching bias reduction for different Matching estimations (Foreign Remittances).

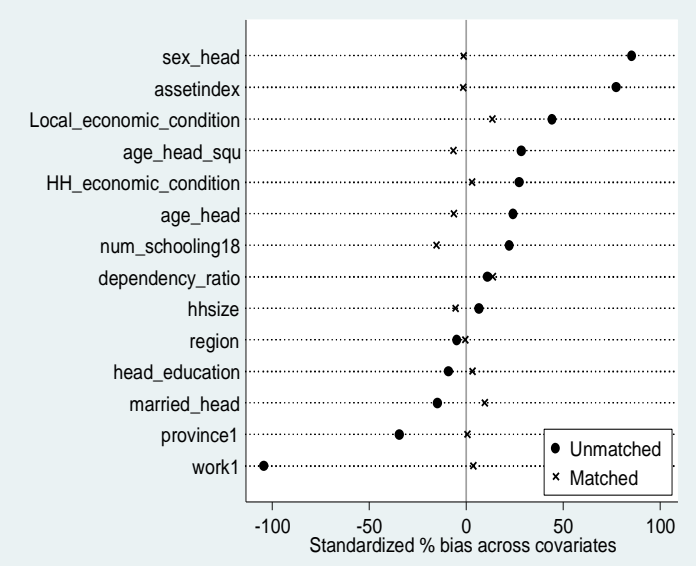

(a) Nearest Neighbor

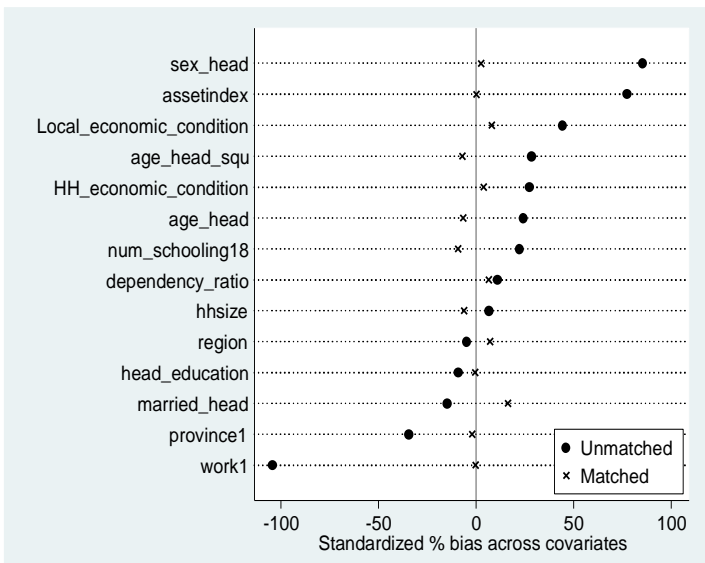

(c) Gaussian Kernel Bandwidth 0.01

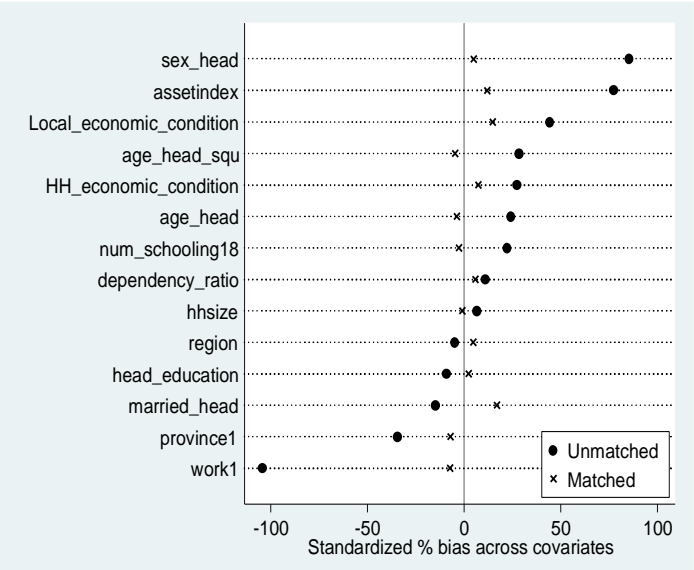

(b) Gaussian Kernel

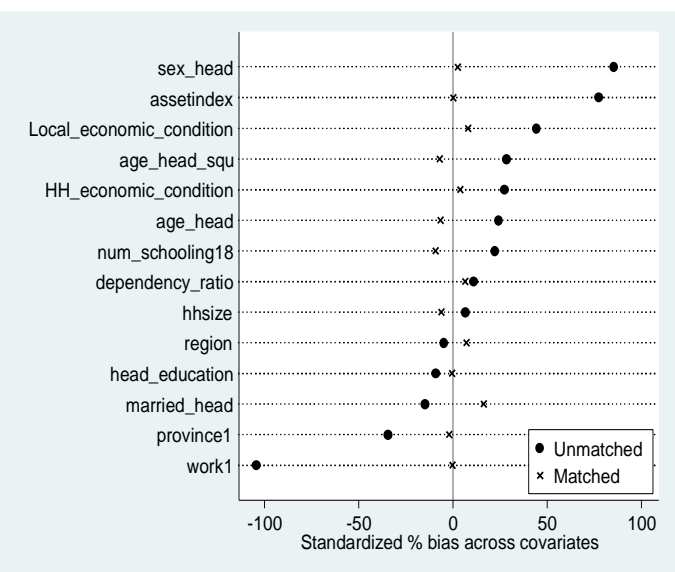

(d) Radius 
Figure A4. Pre- and post-matching bias reduction for different Matching estimations (Domestic Remittances).

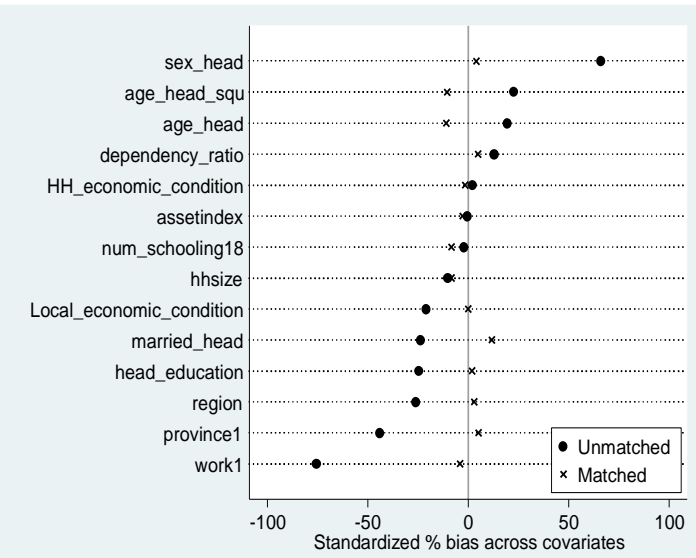

(a) Nearest Neighbor

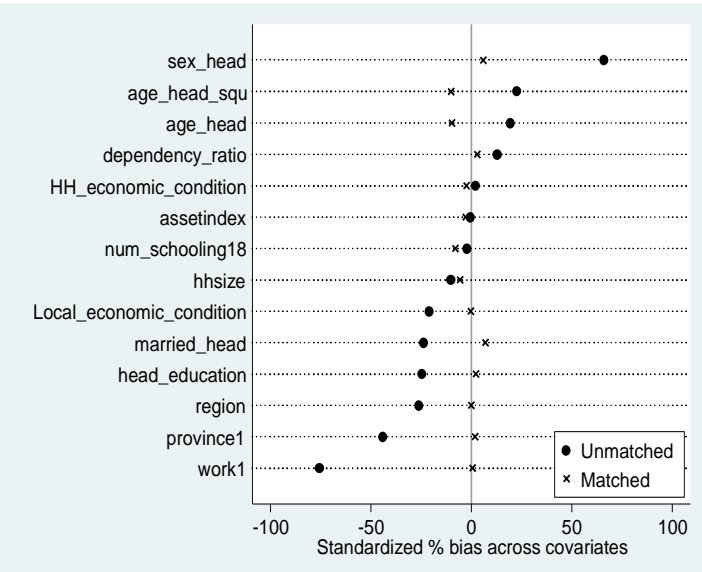

(c) Gaussian Kernel Bandwidth 0.01

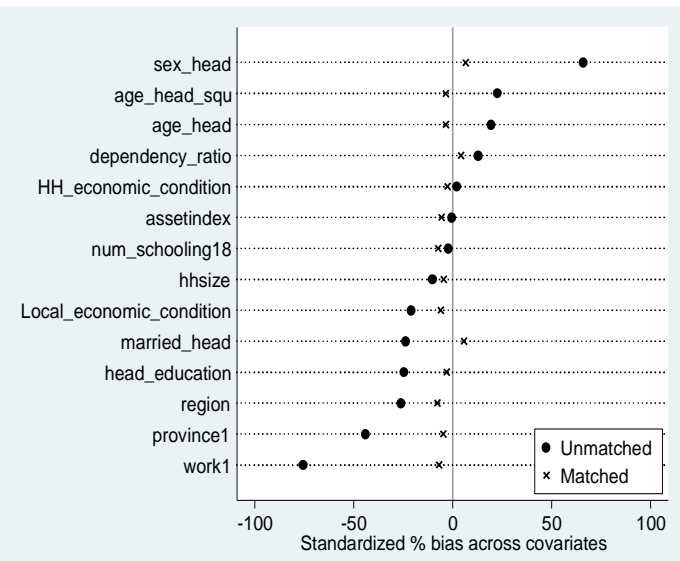

(b) Gaussian Kernel

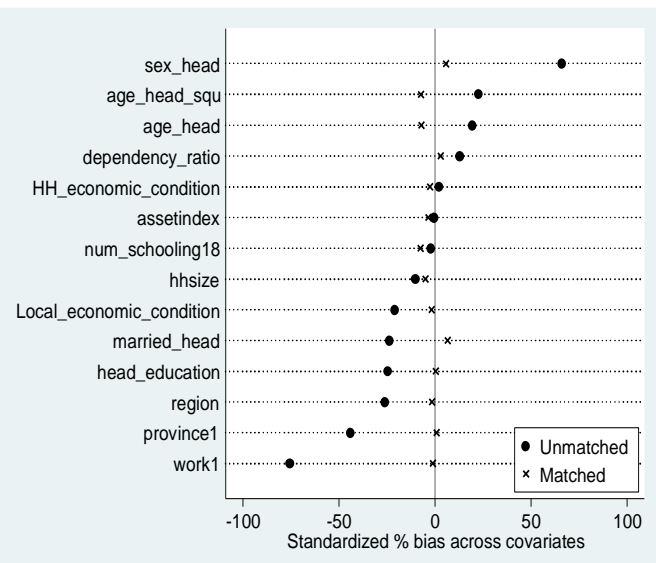

(d) Radius 
Table A12. Quality of Matching Indicators

\begin{tabular}{|c|c|c|}
\hline Test indicator & $\begin{array}{l}\text { Foreign } \\
\text { Remittances }\end{array}$ & $\begin{array}{l}\text { Domestic } \\
\text { Remittances }\end{array}$ \\
\hline \multicolumn{3}{|l|}{ Before Matching } \\
\hline Mean absolute bias & 35.31223 & 25.02 \\
\hline Pseudo $R^{2}$ & 0.258 & 0.146 \\
\hline$L R \chi^{2}(P$-value $)$ & $\begin{array}{l}887.61 \\
(0.000) \\
\end{array}$ & $\begin{array}{l}666.08 \\
(0.000) \\
\end{array}$ \\
\hline \multicolumn{3}{|l|}{ After matching } \\
\hline \multicolumn{3}{|c|}{ Nearest neighbor matching } \\
\hline Mean absolute bias & 6.10 & 5.48 \\
\hline Pseudo $R^{2}$ & 0.007 & 0.007 \\
\hline$L R \chi^{2}(P$-value $)$ & $\begin{array}{l}8.95 \\
(0.834)\end{array}$ & $\begin{array}{l}12.79 \\
(0.543)\end{array}$ \\
\hline \multicolumn{3}{|c|}{ Kernel basedmatching } \\
\hline Mean absolute bias & 6.79 & 5.16 \\
\hline Pseudo $R^{2}$ & 0.012 & 0.004 \\
\hline$L R \chi^{2}(P$-value $)$ & $\begin{array}{l}14.77 \\
(0.394) \\
\end{array}$ & $\begin{array}{l}7.44 \\
(0.917) \\
\end{array}$ \\
\hline \multicolumn{3}{|c|}{ Kernel based matching (b.w 0.01) } \\
\hline Mean absolute bias & 5.46 & 4.24 \\
\hline Pseudo $R^{2}$ & 0.008 & 0.003 \\
\hline$L R \chi^{2}(P$-value $)$ & $\begin{array}{l}9.17 \\
(0.820)\end{array}$ & $\begin{array}{l}5.56 \\
(0.976)\end{array}$ \\
\hline \multicolumn{3}{|l|}{ Radius matching } \\
\hline Mean absolute bias & 6.24 & 3.88 \\
\hline Pseudo $R^{2}$ & 0.009 & 0.002 \\
\hline$L R \chi^{2}(P$-value $)$ & $\begin{array}{l}10.45 \\
(0.728)\end{array}$ & $\begin{array}{l}4.12 \\
(0.995)\end{array}$ \\
\hline
\end{tabular}


Table A13. Rosenbaum bounds sensitivity analysis. Foreign remittances as treatment variable

\begin{tabular}{|c|c|c|c|c|c|c|c|}
\hline & \multirow[t]{2}{*}{$\Gamma$} & \multicolumn{2}{|c|}{$\begin{array}{l}\text { Wilcoxon's signed } \\
\text { rank test }\end{array}$} & \multicolumn{2}{|c|}{$\begin{array}{l}\text { Hodges-Lehmann } \\
\text { pointe stimates }\end{array}$} & \multicolumn{2}{|c|}{$\begin{array}{l}\text { 95\% confidence } \\
\text { Interval }\end{array}$} \\
\hline & & sig+ & sig- & t-hat+ & t-hat- & $\mathrm{CI}+$ & CI- \\
\hline \multirow[t]{3}{*}{ Education } & 1.00 & 0.015 & 0.015 & 0.710 & 0.710 & 0.070 & 1.366 \\
\hline & 1.05 & 0.041 & 0.005 & 0.570 & 0.843 & -0.064 & 1.519 \\
\hline & 1.10 & 0.090 & 0.001 & 0.446 & 0.990 & -0.197 & 1.660 \\
\hline \multirow[t]{2}{*}{ Recreation } & 1.00 & 0.044 & 0.044 & -0.043 & -0.043 & -0.126 & 0.000 \\
\hline & 1.05 & 0.017 & 0.100 & -0.064 & -0.030 & -0.143 & 0.017 \\
\hline \multirow{2}{*}{$\begin{array}{l}\text { Consumer Non- } \\
\text { durables }\end{array}$} & 1.00 & 0.008 & 0.008 & -0.375 & -0.375 & -0.905 & 0.142 \\
\hline & 1.05 & 0.035 & 0.166 & -0.493 & -0.258 & -1.017 & 0.257 \\
\hline \multirow[t]{2}{*}{ Durables } & 1.00 & 0.058 & 0.058 & 0.158 & 0.158 & -0.038 & 0.388 \\
\hline & 1.05 & 0.124 & 0.023 & 0.115 & 0.201 & -0.084 & 0.441 \\
\hline
\end{tabular}

Note: * Gamma - log odds of differential assignment due to unobserved factors sig+ - upper bound significance level sig- - lower bound significance level t-hat+ - upper bound Hodges-Lehmann point estimate t-hat- - lower bound Hodges-Lehmann point estimate CI+ - upper bound confidence interval $(a=.95)$ CI- - lower bound confidence interval $(a=.95)$

Table A14. Rosenbaum bounds sensitivity analysis. Domestic remittances as treatment variable

\begin{tabular}{|c|c|c|c|c|c|c|c|}
\hline & \multirow[t]{2}{*}{$\bar{\Gamma}$} & \multicolumn{2}{|c|}{$\begin{array}{l}\text { Wilcoxon's signed } \\
\text { rank test }\end{array}$} & \multicolumn{2}{|c|}{$\begin{array}{l}\text { Hodges-Lehmann } \\
\text { point estimates }\end{array}$} & \multicolumn{2}{|c|}{$\begin{array}{l}\text { 95\% confidence } \\
\text { Interval }\end{array}$} \\
\hline & & $\overline{\text { sig+ }}$ & sig- & t-hat+ & t-hat- & $\mathrm{CI}+$ & $\overline{\mathrm{CI}-}$ \\
\hline \multirow[t]{5}{*}{ Health } & 1.00 & 0.000 & 0.000 & 0.648 & 0.648 & 0.366 & 0.938 \\
\hline & 1.10 & 0.000 & 0.000 & 0.501 & 0.799 & 0.216 & 1.098 \\
\hline & 1.20 & 0.006 & 0.000 & 0.365 & 0.938 & 0.079 & 1.245 \\
\hline & 1.30 & 0.050 & 0.000 & 0.241 & 1.071 & -0.044 & 1.389 \\
\hline & 1.25 & 0.107 & 0.000 & 0.182 & 1.133 & -0.101 & 1.457 \\
\hline \multirow[t]{2}{*}{ Housing } & 1.00 & 0.075 & 0.075 & -0.855 & -0.855 & -2.039 & 0.310 \\
\hline & 1.05 & 0.025 & 0.181 & -1.172 & -0.534 & -2.353 & 0.616 \\
\hline \multirow[t]{2}{*}{ Education } & 1.00 & 0.024 & 0.024 & 0.420 & 0.420 & 0.000 & 0.863 \\
\hline & 1.05 & 0.073 & 0.006 & 0.301 & 0.537 & -0.088 & 0.983 \\
\hline \multirow[t]{3}{*}{ Recreation } & 1.00 & 0.000 & 0.000 & -0.033 & -0.033 & -0.096 & 0.000 \\
\hline & 1.10 & 0.000 & 0.010 & -0.062 & -0.003 & -0.123 & 0.000 \\
\hline & 1.20 & 0.000 & 0.081 & -0.096 & 0.000 & -0.160 & 0.000 \\
\hline
\end{tabular}

Note: * Gamma - log odds of differential assignment due to unobserved factors sig+ - upper bound significance level sig- - lower bound significance level t-hat+ - upper bound Hodges-Lehmann point estimate t-hat- - lower bound Hodges-Lehmann point estimate CI+ - upper bound confidence interval $(\mathrm{a}=.95) \mathrm{CI}-\quad$ - lower bound confidence interval $(\mathrm{a}=.95)$ 
${ }^{1}$ The work status of female head in Pakistan does not appear to substantially correlate with the households' income levels.

2 The findings are estimated using Stata rbounds user module (Diprete and Gangl, 2004).

${ }^{3}$ The test was only carried out for ATT significantly different from zero.

${ }^{4}$ The comparisons are based on Gaussian Kernel estimation.

${ }^{5}$ Results are available upon request. 